\title{
Mechanical and Fatigue Strength Assessment of Friction Stir Welded Plates of Magnesium Alloy AZ31B
}

\author{
Carlos Fernando Luna ${ }^{1}$, Fernando Franco Arenas², Victor Ferrinho Pereira ${ }^{3}$, Julián Arnaldo Ávila ${ }^{3,4}$ \\ 1 Servicio Nacional de Aprendizaje - SENA, Manizales, Caldas, Colombia. \\ 2 Universidad del Valle, Escuela de Ingeniería de Materiales, Cali, Colombia. \\ ${ }_{3}$ Centro Nacional de Pesquisa em Energia e Materiais - CNPEM, Laboratório Nacional de Nanotecnologia - LNNano, Campinas, \\ SP, Brasil. \\ ${ }^{4}$ Universidade Estadual Paulista - UNESP, Campus de São João da Boa Vista, São João da Boa Vista, SP, Brasil.
}

Received: 27 Nov., 2017

Accepted: 23 Mar., 2018

E-mail: julian.avila@unesp.br (JAA)
This is an Open Access article distributed under the terms of the Creative Commons Attribution Non-Commercial License which permits unrestricted non-commercial use, distribution, and reproduction in any medium provided the original work is properly cited.

\begin{abstract}
Light-alloys play a significant role in saving weight in automotive and aerospace industries; however, a few joining methods guarantee mechanical and fatigue strengths for high performance application. Even conventional arc welding processes do not offer constant quality joints. Therefore, this study uses an alternative solid-state welding process, friction stir welding (FSW), to analyze post processing microstructures and assess mechanical and fatigue strength. Magnesium alloy AZ31B plates were welded using different welding parameters in a dedicated FSW machine. The effect of the spindle speed $(\omega)$ and welding speed $(v)$ on the microstructure, the tensile strength and fatigue were studied. The stirred zone (SZ) at the FS-welded joints presented a microstructure composed by homogeneous equiaxial grains, refined by dynamic recrystallization. A rise in grain size, weld bead width, tensile and fatigue strengths with the increase of speed ratio $(\omega / \mathrm{v})$ were observed. Results of the fatigue and mechanical strength here presented outperformed results from welds made with conventional milling machines.
\end{abstract}

Key-words: Magnesium AZ31B; Fatigue strength; Tensile strength; Friction stir welding; FSW.

\section{Avaliação da Resistência Mecânica e à Fadiga de Chapas Soldadas por Atrito com Pino não Consumível da Liga de Magnésio AZ31B}

\begin{abstract}
Resumo: Ligas leves apresentam uma importante função na indústria, na redução de peso na indústria automotiva e aeroespacial. No entanto, poucos métodos de união garantem a resistência mecânica e de fadiga necessárias para aplicações de alto desempenho. Inclusive, processos convencionais de soldagem a arco, nem sempre fornecem juntas soldadas de qualidade. Portanto, este estudo usa um processo de soldagem alternativo em estado sólido, conhecido por soldagem por atrito com pino não consumível (SAPNC). São analisadas as microestruturas após soldagem, a resistência mecânica e de fadiga. Chapas de magnésio da liga AZ31B foram soldadas com diferentes parâmetros em uma máquina dedicada para SAPNC. Foram estudados os efeitos da velocidade de soldagem (v), velocidade de rotação ( $\omega$ ) na microestrutura, resistência mecânica e de fadiga. A zona misturada (ZM) das juntas por SAPNC mostrou microestruturas compostas por grãos homogêneos e equiaxiais, refinados por recristalização dinâmica. Foi observado um aumento do tamanho de grão, largura do cordão, resistência mecânica e de fadiga com o aumento da relação de velocidade $(\omega / \mathrm{v})$. Os resultados da resistência mecânica e fadiga apresentados ultrapassaram resultados de juntas similares realizadas em máquinas fresadoras convencionais.
\end{abstract}

Palavras-chave: Magnésio AZ31B; Resistência à fadiga; Resistência mecânica; Soldagem por atrito com pino não consumível; SAPNC.

\section{Introduction}

Welded joints tended to exhibit microscopic defects such as porosities, impurities and even cracks [1,2]. These defects can be overcome by using FSW, welding process in the solid state, invented by TWI in 1991 [3]. The FSW process consumes a very small amount of energy without requiring filler materials, this allows to obtain high speed welded joints with superior mechanical properties compared to conventional arc welding [1,4]. In addition, light alloys welded by FSW dismiss the gas shield protection. The FSW process was initially used in aluminum alloys, but this process has recently been focused on new 
structural applications seeking to improve resistance. FSW of aluminum [5-7] and magnesium [6] alloys has a great potential of application in the aerospace and automotive industries [7].

The spindle speed (v), the welding speed $(\omega)$, downward force and pin geometry are the most relevant variables of FSW. These variables influence the geometry and penetration of the weld, which influence the mechanical properties of the different zones of the welded joint [5,6]. In previous studies, Franco [8] used a milling machine to perform FSW sheet Mg alloy AZ31B, achieving a mechanical efficiency of 93\%, and a reduction of grain size up to $85 \%$ in the SZ. Similarly, Ávila et al. [1] used a milling machine, and evaluated the tensile strength and fatigue strength, finding a mechanical efficiency up to $96 \%$, and a fatigue efficiency of $70 \%$ with respect to the BM. On the other hand, Padmanaban and Balasubramanian [9], evaluated the fatigue strength of the AZ31B Mg alloy, of welded joints with laser, with GTAW, with pulsed arc and by FSW, proving that FSW joints exceeded the fatigue strength of the welds obtained by the GTAW process. Most studies in FSW of Mg alloy AZ31B focused on determining the tensile strength, the microstructure in the SZ, and determination of alloy defects, without assessing the fatigue resistance. Therefore, this study aims to characterize the joints welded by the friction process of a magnesium alloy AZ31B, including the tensile and fatigue behavior.

\section{Experimental Methodology}

The effects of the spindle speed $(v)$ and welding speed $(\omega)$ were studied on the tensile strength, fatigue resistance and micro hardness of an AZ31B magnesium alloy welded by FSW. Additionally, a microstructural characterization was carried out through the welded joints seeking correlations with welding parameters. Nine experimental conditions were used, three spindle speeds and three welding speeds, as shown in Table 1 . Figure 1 shows the distribution of the experimental units, which corresponds to extruded plates of AZ31B Mg alloy 90-mm wide $\times 120-\mathrm{mm}$ long $\times 3.20-\mathrm{mm}$ thick butt-welded by FSW. The end effects of the welded joints were discarded by cutting the $15 \mathrm{~mm}$ length final and initial segments of the weld beads. Table 2 shows the chemical composition (\% by weight) of the AZ31B alloy. Welds were performed in a dedicated TTI FSW welding machine, which allowed to have a constant tool tip penetration control along the weld bead. A cylindrical tool with a threaded pin, show in Figure 2, made of a $\mathrm{H} 13$ quenched and tempered steel to guarantee a minimum hardness of 50 Rockwell $\mathrm{C}$ was

Table 1. Experimental conditions in terms of spindle speed and travel speed ratio $(\omega / \mathrm{v})$.

\begin{tabular}{cccc}
\hline & \multicolumn{3}{c}{$\mathbf{v}(\mathbf{m m} / \mathbf{m i n})$} \\
\cline { 2 - 4 } & $\mathbf{1 0 0}$ & $\mathbf{2 0 0}$ & $\mathbf{3 0 0}$ \\
1200 & 12 & 6 & 4.0 \\
1600 & 16 & 8 & 5.3 \\
2000 & 20 & 10 & 6.7 \\
\hline
\end{tabular}

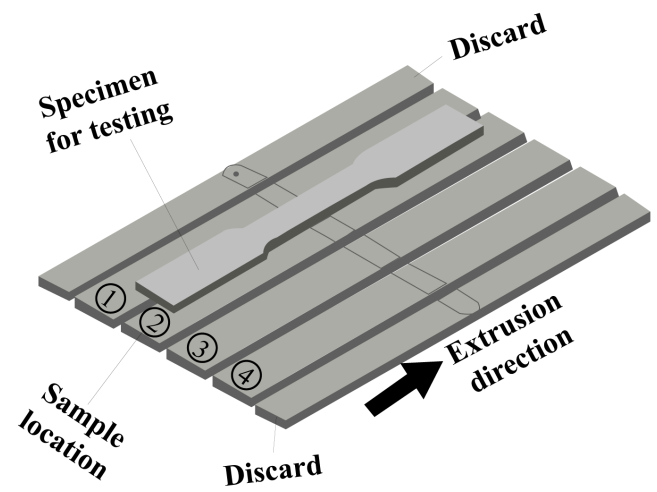

Figure 1. Scheme of the friction stir butt-welded joints (experimental unit) and its sectioning in samples for different assessments and characterizations. 
Table 2. Chemical composition (\% by weight) of base metal, alloy AZ31B Mg [1].

\begin{tabular}{ccccccc}
\hline Mg alloy & Al & Mg & Fe & Mn & Si & Zn \\
AZ31B & 2.8 & Bal & 0.007 & 0.52 & 0.09 & 1.0 \\
\hline
\end{tabular}
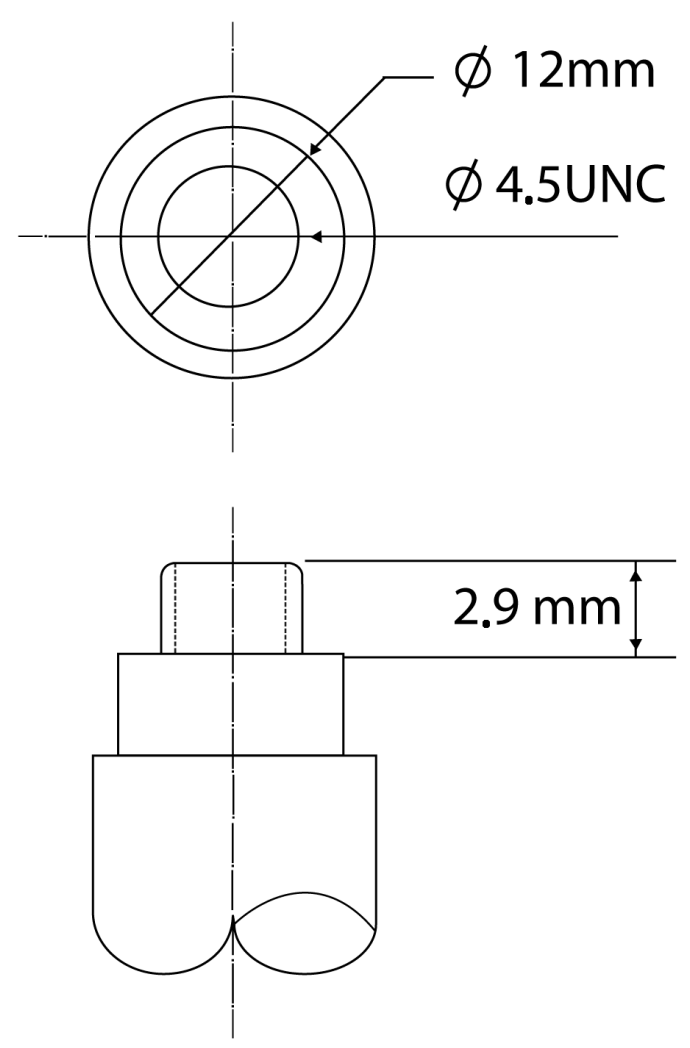

Figure 2. Schematic view of the cylindrical tool with a threaded pin, made of a H13 steel with $50 \mathrm{HRC}$.

used. During welding a head inclination (tool tilt) of $1^{\circ}$ was used, counter clockwise tool rotation and position control were used to perform the welds. Quality assessment of the welded joints was performed using a stereomicroscope.

For this study, the variables considered as input factors were the welding and spindle speed, each factor with 3 levels, as shown in Table 1. The experimental design was a factorial design $3^{2}, 2$ factors with 3 levels for a total of 9 treatments.

The microstructure characterization and hardness measurements were performed through metallographic analysis with optical microscope. A random sample of each treatment was selected, and 8 measurements were made in each sample. The grain measurements were done under the ASTM E112 [10] standard requirements. For the Vickers hardness tests, 100 gf for 10 seconds were applied in each spot, 8 separate points every 2 mm respectively.

Tensile tests were performed according to ASTM E8 [11] standard on a universal test machine, four (4) replicates were performed for a total of 36 tests. The response variable of this design was the ultimate tensile stress. Fatigue tests were performed according to ASTM E466 [12] by using servo-hydraulic machine. Axial and tensile loading configuration, a sinusoidal wave with frequency of $30 \mathrm{~Hz}$ and Stress Ratio equal to 0.1 ( $R=0.1$ ) were used during fatigue tests. At first, the test response variable was the fatigue life cycle with a load of $70 \%$ of the tensile strength of the base material. The welded joint presenting the best mechanicals properties, tensile strength and fatigue resistance was selected to perform a complete fatigue curve assessment. Thereafter, 16 samples from this selected condition were used to build the fatigue strength (S) versus number of cycles (N) curves (S-N). Three stress levels were used during fatigue tests, 4 samples for $70 \%, 5$ samples for $60 \%$ and 7 samples for $50 \%$ of ultimate strength of the base metal. An error of $5 \%$ was assumed and a confidence level of $90 \%$ was selected. 


\section{Results and Discussion}

\subsection{Welding features}

Figure 3 shows a summary of the data collected, loading and displacement during the welding process. Downward force decreases as the spindle speed increases. In addition, downward force increases for faster travel speeds. Both observations are explained by the produced and dissipated heat, as the heat increases the base material offers less resistance to be penetrated, therefore the needed force to keep the tool on the programed position decreases. High spindle speeds produce much more heat than slow speeds, and higher travel speeds dissipate larger amount of heat.
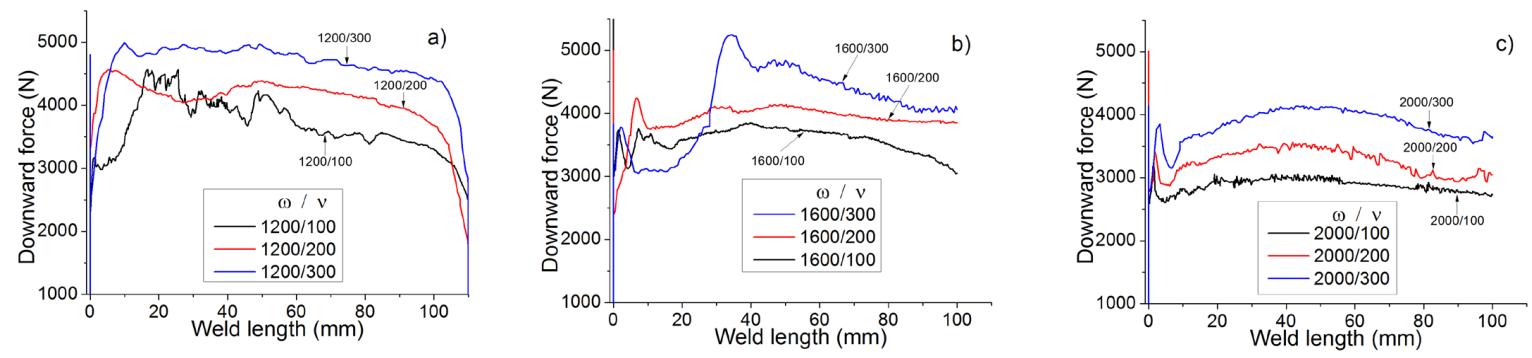

Figure 3. Conventional curves of weld parameters using penetration control mode: (a) 1200 (b) 1600 and (c) $2000 \mathrm{rpm}$ in combination with 100, 200 and $300 \mathrm{~mm} / \mathrm{min}$.

\subsection{Metallography}

Analysis of the welded joints macrostructures, carried out in the cross-section by means of the stereo microscope, allows to observe the conical shape of the bead with complete penetration up to the root. In addition, measurements of the width of the bead, grain size and maximum temperatures are shown in Table 3. Temperature estimation equation can be explained according to the expression found by Arbegast and Hartley, see Equation 1 , maximum temperature $\mathrm{T}_{\max }$ is proportional to the $\mathrm{Mg}$ melting temperature $\left(\mathrm{Tf}=650{ }^{\circ} \mathrm{C}\right)$, and to the spindle speed squared - welding speed $\left(\omega^{2} / v\right)$ ratio, where $\alpha$ and k are material's constants, $\alpha=0.05$ and k=0.7 [4]. Grain size, bead width and maximum temperature increase with the $\omega / v$ and $\omega^{2} / v$ ratios, thus spindle speed plays a key role during welding.

$$
T_{\max }=k\left(\frac{\omega^{2}}{v \times 10^{4}}\right)^{\alpha} T_{f}
$$

Table 3. Speed ratio effect in the bead width, grain size of stir zone and $\mathrm{T}_{\max }$ calculated by Equation 1.

\begin{tabular}{|c|c|c|c|c|c|c|c|}
\hline$\omega$ & $\mathbf{v}$ & $\omega / v$ & $\omega^{2} / v$ & Grain size & Grain size & Bead width & $\mathbf{T}_{\max }$ \\
\hline$\left(\right.$ rev min $\left.^{-1}\right)$ & $\left(\mathrm{mm} \mathrm{min}^{-1}\right)$ & (rev/mm) & $\left(\mathrm{rev}^{2} / \mathrm{mm}\right)$ & No. ASTM [10] & $(\mu \mathrm{m})$ & $(\mathrm{mm})$ & $\left({ }^{\circ} \mathrm{C}\right)$ \\
\hline \multirow[t]{3}{*}{1200} & 100 & 12 & 14400 & 11.52 & 6.84 & 5.9 & 463 \\
\hline & 200 & 6 & 7200 & 11.88 & 6.00 & 5.4 & 448 \\
\hline & 300 & 4 & 4800 & 12.00 & 5.60 & 5.3 & 439 \\
\hline \multirow[t]{3}{*}{1600} & 100 & 16 & 25600 & 9.88 & 11.70 & 6.9 & 477 \\
\hline & 200 & 8 & 12800 & 10.53 & 9.31 & 6.5 & 461 \\
\hline & 300 & 5 & 8533 & 10.54 & 9.28 & 6.5 & 451 \\
\hline \multirow[t]{3}{*}{2000} & 100 & 20 & 40000 & 9.38 & 13.92 & 7.6 & 488 \\
\hline & 200 & 10 & 20000 & 9.95 & 11.41 & 7.3 & 471 \\
\hline & 300 & 7 & 13333 & 10.08 & 10.91 & 7.2 & 462 \\
\hline Base Material & & & & 5.10 & 61.50 & --- & --- \\
\hline
\end{tabular}


The heat input in the FSW and plastic deformation produced in SZ generate dynamic recrystallization, causing nucleation and formation of new grains, with smaller sizes than the other areas of the welded joints, as shown in Figure 4. Grain size at SZ tended to increase with the spindle speed and the speed ratio $(\omega / v)$, as shown in Table 3 as reported by Franco [8]. SZ presented a microstructure with fine equiaxial grains, with uniform size through the transverse section, also as reported by Suhuddin et al. [13]. The thermomechanically affected zone (TMAZ) arises from an insufficient heating temperature for dynamic recrystallization during the FSW [1]. This zone is located between stir zone (SZ) and base metal (BM), with some characteristics similar SZ, that made difficult its differentiation. The heat affected zone (HAZ) was located after the SZ towards the base metal, as show in Figure 4. The study of the grain size was performed on all samples.
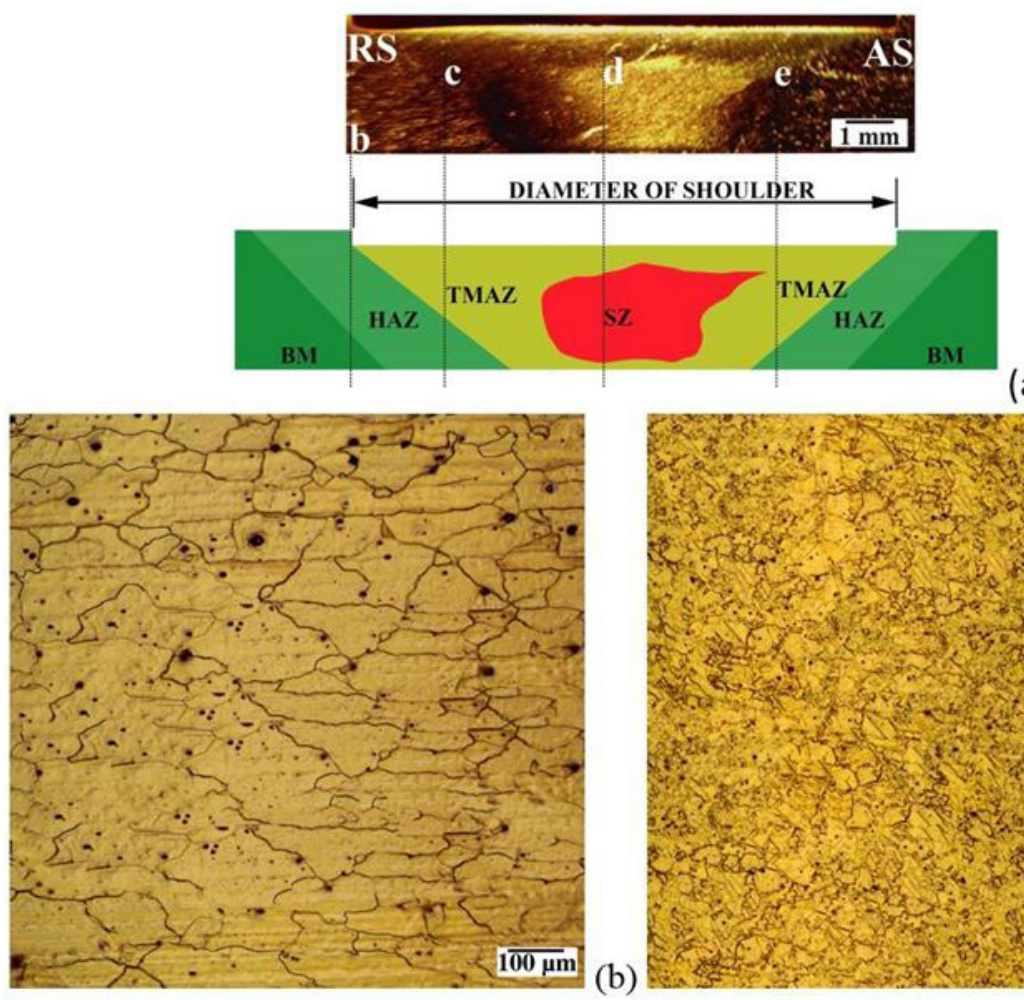

(a)
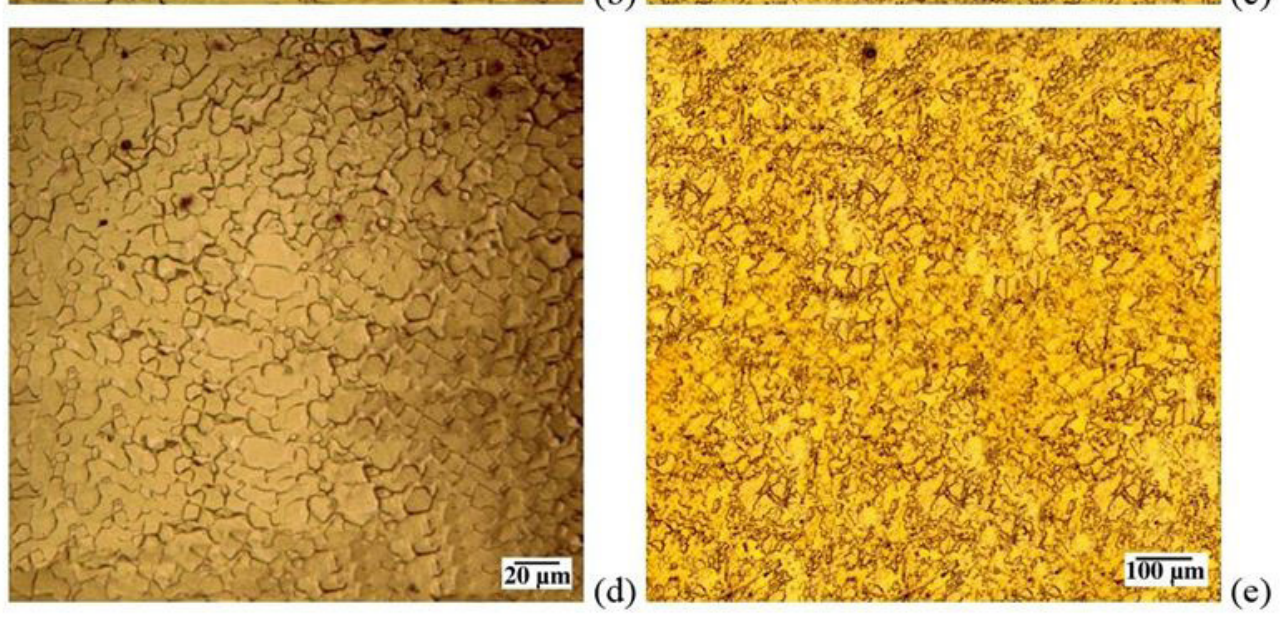

Figure 4. Typical and representative macro and microstructure of different zones of the welded joint. Speed ratio of $5.3\left(1600 / 300 \mathrm{rev} \mathrm{mm}^{-1}\right)$. (a) Cross-section macro view and schematic representation of the welded joint. Micrographs: (b) base metal (BM), (c) thermomechanically affected zone of the retreating side (TMAZ-RS), (d) stir zone (SZ), and (e) TMAZ of the advancing side (TMAZ-AS). 


\subsection{Micro hardness test}

Figure 5 shows the microhardness values made every $2 \mathrm{~mm}$ along the cross section of the welded joint. SZ presented a hardness value similar to BM [14], an average hardness of $50.25 \pm 0.50$ Vickers was obtained (value with a confidence level of $95 \%$ ). It was also observed a tendency for the SZ hardness to increase, as the travel speed increase and keeping the spindle speed constant.

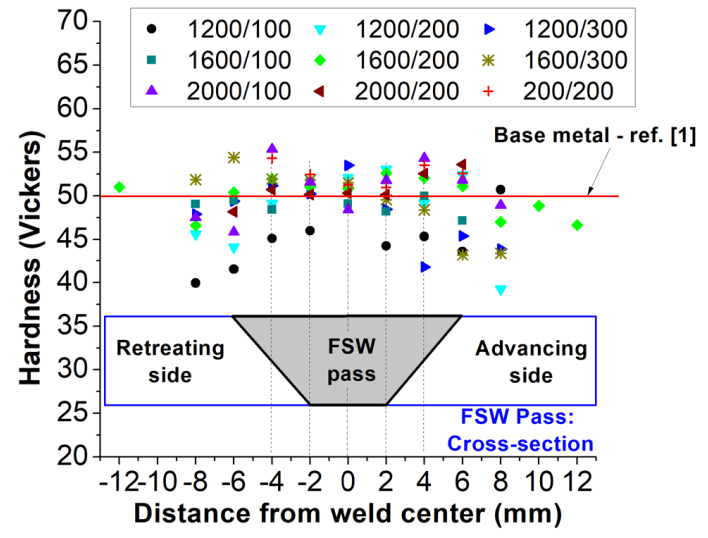

Figure 5. Hardness profiles obtained in FSW joints.

\subsection{Tensile tests}

Figure 6 shows the final resistance as a function of the speed ratio $\omega / v$. The tensile strength tended to increase, by increasing the speed ratio, until the ratio of $10 \mathrm{rev} \mathrm{mm}^{-1}$. From this speed ratio, the higher rotation speeds of the spindle and the lower welding speeds generated an excessive heat, diminishing the mechanical properties [8], at the time that the grain size increased and the hardness decreased. For intermediate speed ratios, the mechanical properties of the weld joints seem to depend more on the speed of the spindle and the generation of heat. For welded joints with a speed ratio of $10 \mathrm{rev} / \mathrm{mm}$, the maximum mechanical efficiency corresponded to $97.6 \%$ of the base material, which exceeds the results obtained by Avila et al. [14] on similar joints made with a milling machine.

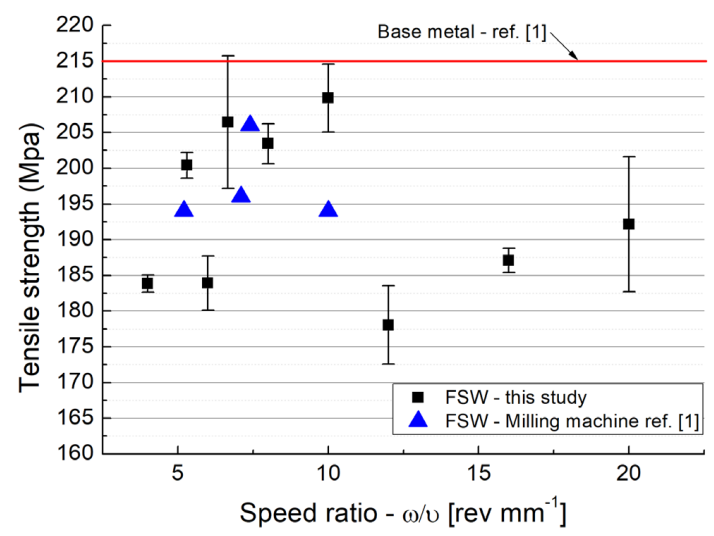

Figure 6. Ultimate tensile strength versus speed ratio $(\omega / v])$.

Failures on the tested joints occurred on a plane of approximately $45^{\circ}$ with reference to the load axis of the tested samples through the transition zone between base metal (BM) and THZ, failing $55.6 \%$ of the times on the advance side HAZ-AS, $27.8 \%$ on the retreating side HAZ-RS, and 16.7\% failed on the base material BM (See Figure 4). 
Most of these failures were generated because the maximum cutting efforts coincided with the transition zone where a low mechanical resistance zone was generated.

\subsection{Fatigue tests}

The fatigue tests were performed for the experimental treatments with better results in tension corresponding to the spindle speed 1600 and $2000 \mathrm{rpm}$. Figure 7 shows the fatigue strength evaluated using $70 \%$ of the ultimate tensile strength $\left(\mathrm{S}_{\mathrm{UT}}\right)$ of $\mathrm{BM}, \mathrm{S}_{\max }=150 \mathrm{MPa}$.

Speed ratios between 5 and $10(\mathrm{rev} / \mathrm{mm})$ presented the highest mechanical strength, as shown in Figure 6 , and speed ratios between 8 and $20(\mathrm{rev} / \mathrm{mm}$ ) have the best fatigue results (see Figure 7). Thus, samples with the

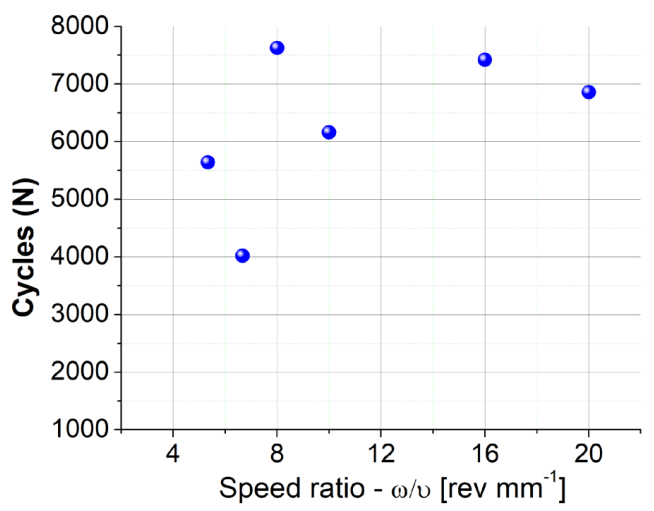

Figure 7. Resistance to fatigue when varying the speed ratio $(\omega / v)$.

best quasi static tensile behavior does not correspond to those with the best fatigue tests results. A similar behavior was reported by Chowdhury et al. [15], who welded joints of the Mg AZ31B-H24 alloy.

The best fatigue behavior was obtained for the speed ratio of $8 \mathrm{rev} / \mathrm{mm}(1600 / 200 \mathrm{rev} / \mathrm{mm})$, so it was selected to perform the complete S-N curve. The S-N curves are least-square fits to each set of data of the Basquin's equation $\log (N)=\log (A)+m \log (S R)$, where $N$ is the number of cycles to failure in fatigue tests, $A$ the intercept, and $m$ the slope of the curve. As shown in Figure 8 and Table 4, the base metal (BM) presented the best fatigue behavior, with a calculated fatigue strength (MPa) in $2 \times 10^{6}$ cycles higher than the FSW and GTAW joints. Therefore, by analyzing the slope of the curves, the higher the best, the FSW joints performed in this study presented a better behavior than FSW joints performed in a milling machine [1,9]. Hence, a better controlled welding process can provide better quality joints.

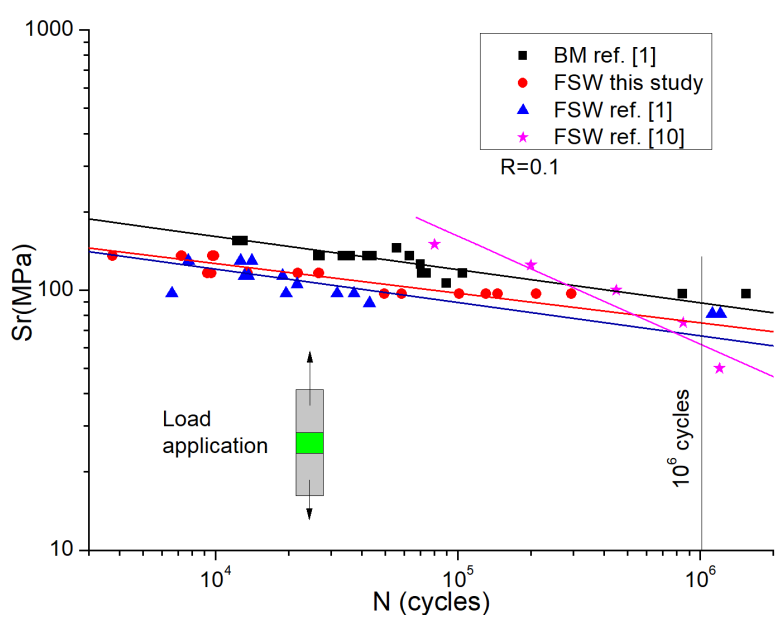

Figure 8. Comparative S-N curves. 
Table 4. Summary of fatigue properties and comparison with other authors of BM, FSW and GTAW joints.

\begin{tabular}{|c|c|c|c|c|c|c|}
\hline Specimen & A & m & $\begin{array}{l}\text { Fatigue strength } \\
\text { (MPa), } 2 \times 10^{6} \text { cycles }\end{array}$ & Test to failure & $\begin{array}{l}\text { Run out tests } \\
\text { (No failure) }\end{array}$ & $\begin{array}{c}\text { Standard } \\
\text { deviation of } \\
\log N\end{array}$ \\
\hline FSW (This study) & 22.43 & -8.77 & 69.00 & 16.00 & 0.00 & 0.60 \\
\hline BM (ref. [1]) & 20.25 & -7.83 & 81.00 & 19.00 & 2.00 & 0.52 \\
\hline FSW (ref. [1]) & 19.08 & -7.80 & 60.00 & 14.00 & 0.00 & 0.57 \\
\hline GTAW (ref. [1]) & 13.85 & -5.20 & 48.00 & 16.00 & 0.00 & 0.61 \\
\hline BM (ref. [9]) & 10.36 & -2.80 & 72.00 & 5.00 & --- & 0.56 \\
\hline FSW (ref. [9]) & 9.35 & -2.40 & 40.00 & 5.00 & --- & 0.48 \\
\hline GTAW (ref. [9]) & 9.07 & -2.33 & 49.00 & 5.00 & --- & 0.46 \\
\hline
\end{tabular}

\section{Conclusions}

- Mechanical properties of friction stir welded plates changes with the speed ratio $(\omega / v)$. A tendency to increase the grain size and the weld bead width by increasing the speed ratio was observed. On the other hand, the hardness, the tensile and fatigue strength in the stir zone increased slightly as the relation $\omega / v$ decreased;

- Stir zone in friction stir welded plates of an AZ31B alloy was characterized by a microstructure comprising equiaxial homogeneous grains refined by dynamic recrystallization. Then, a tendency to increase hardness with reference to BM is normally observed. Smaller grains increase the number of borders, and more barriers for crack propagation, however, quasi-statics and fatigue properties do not overpass base material standard;

- Welds performed in automatic machine control designed for the FSW process presents better results than welds performed in conventional milling machines, as compared with other studies for tensile and fatigue properties.

\section{References}

[1] Avila JAD, Jaramillo HE, Franco AF. Fatigue of friction stir and GTAW welded AZ31B magnesium alloy. In: American Society of Mechanical Engineers. ASME 31 International Conference on Offshore Mechanics \& Arctic Engineering; Rio de Janeiro. Rio de Janeiro: ASME; 2012. p. 365-370.

[2] Afrin N, Chen DL, Cao X, Jahazi M. Microstructure and tensile properties of friction stir welded AZ31B magnesium alloy. Materials Science and Engineering A. 2008;472(1-2):179-186. http://dx.doi.org/10.1016/j.msea.2007.03.018.

[3] Thomas W, Nicholas ED, Staines D, Tubby PJ, Gittos MF. FSW process variants and mechanical properties. Welding in the World. 2005; 49(3-4): 4-11. http://dx.doi.org/10.1007/BF03266468.

[4] Mishra RS, Ma ZY. Friction stir welding and processing. Materials Science and Engineering R Reports. 2005;50(1-2):1-78. http:// dx.doi.org/10.1016/j.mser.2005.07.001.

[5] Rambabu P, Prasad NE, Kutumbarao VV, Wanhill RJH. Chapter 2: Aerospace Materials and Material Technologies Aerospace Materials and Material Technologies. Volume 1: Aerospace Materials, 29-52 (2017). http://dx.doi.org/10.1007/978-98110-2134-3_2.

[6] Ugender S, Kumar A, Reddy AS. Microstructure and mechanical properties of AZ31B magnesium alloy by friction stir welding. Procedia. Materials Science. 2014;6:1600-1609.

[7] Nicholas ED, Thomas WM. A review of friction processes for aerospace applications. International Journal of Materials \& Product Technology. 1998;13:45-55.

[8] Franco F. Mechanical efficiency in the friction stir welding of magnesium alloy AZ31B. Ingeniería y Competitividad. 2012;14:23-30.
[9] Padmanaban G, Balasubramanian V. Fatigue performance of pulsed current gas tungsten arc, friction stir and laser beam welded AZ31B magnesium alloy joints. Materials \& Design. 2010;31(8):3724-3732. http://dx.doi.org/10.1016/j. matdes.2010.03.013.

[10] ASTM International. ASTM E112-13 Standard Test Methods for Determining Average Grain Size. West Conshohocken: ASTM International, 2013. http://dx.doi.org/10.1520/E0112.

[11] ASTM International. E8/E8M-16a Standard Test Methods for Tension Testing of Metallic Materials. West Conshohocken: ASTM International; 2016.

[12] ASTM International. E466 Practice for Conducting Force Controlled Constant Amplitude Axial Fatigue Tests of Metallic Materials. West Conshohocken: ASTM International; 2016.

[13] Suhuddin UFHR, Mironov S, Sato YS, Kokawa H, Lee CW. Microstructure evolution during friction-stir welding of AZ31 magnesium alloy. Acta Materialia. 2009;57(18):5406-5418. http://dx.doi.org/10.1016/j.actamat.2009.07.041.

[14] Avila JAD, Franco AF, Jaramillo HE. Evaluación de la resistencia de a la tensión y la fatiga de uniones soldadas por fricción agitación de la aleación de magnesio AZ31B. Revista Latinoamericana de Metalurgia y Materiales. 2012;32:71-78.

[15] Chowdhury SM, Chen DL, Bhole SD, Cao X. Effect of pin tool thread orientation on fatigue strength of friction stir welded AZ31B-H24 Mg butt joints. Procedia Engineering. 2010;2(1):825833. http://dx.doi.org/10.1016/j.proeng.2010.03.089. 